\title{
Enclavic tourism spaces: Territorialization and bordering in tourism destination development and planning
}

\section{Introduction}

The deepening acceleration of globalization has created notions of a "borderless world" (Ohmae, 1990) and a "world of flows and networks" (Castells, 1996) where distance and geography seem to no longer matter (van Houtum, Kramsch, \& Zierhofer, 2005). Recent discussions of "mobility turn" and the mobilities paradigm in social sciences in general have strengthened these views by emphasizing the relationality of distant places and spaces over territoriality and fixed borders (see Hannam, Sheller, \& Urry, 2006). Obviously the processes of globalization and increasing mobility are interrelated and they connect places, people, resources, and goods in new and innovative ways where regional economies are increasingly integrated and distant locations are ever more interdependent on each other.

While there are deepening economic, political, and cultural relationships and increasing "rights of mobility" and encounters in transnational contexts (Gibson, 2010), there are also processes challenging the flexibility and fluidity of contemporary societies and citizens (Turner, 2007). From this perspective globalization, networks, and flows have not fully displaced territoriality and bordering practices (Paasi, 2009), and even tourism and tourists' movement are not "free in any absolute sense" (Britton, 1991, p. 452). Obviously this notion applies to local populations in tourism destinations and host-guest relations as there are often various bordering practices separating visitors and locals and their movement in destination areas. These implicit or explicit ways of differentiating spaces and activities for tourists and locals are typical in many peripheral 
destinations, especially in the Global South (see Brohman, 1996; Carlisle \& Jones; 2012; Freitag, 1994; Mbaiwa, 2005; Rogerson, 1990), but they can also be found in urban and suburban settings (Cohen \& Neal, 2012; Dürr, 2012; Hampton, 2010; Judd, 1999; Simpson, 2016). In tourism research they are usually referred to as tourism enclaves.

Generally, tourism enclaves are seen as products of global capitalism and a non-locally driven neoliberal market economy (see Brohman, 1996; Shaw \& Shaw, 1999). While representing transnational forces, they are also deeply related to certain kinds of tourism planning and development modes in destination societies. These contemporary approaches in development and planning are often categorized under neoliberal governance, which emphasizes the role of the markets rather that the state in guiding and controlling the development discourses and practices (Hart, 2001, 2004). Tourism enclaves are exclusively planned spaces (e.g., all-inclusive resorts and gated recreational communities) that contain all or a vast majority of the facilities and services needed for tourists who have limited possibilities and/or desire to leave the enclave. At the same time, as stated above, locals' access to these spaces can be regulated or their right to enter is based on a certain "given role," such as a gardener, janitor, or cleaner. Thus, these enclaves are usually in some ways separated from the surrounding communities and their social realities (see Buzinde \& Manuel-Navarrete, 2013; Judd, 1999; Torres \& Momsen, 2005).

Tourism enclaves and related spatial differentiation are not a new phenomenon in tourism planning and development (see, e.g., Gilbert, 1939; MacCannell, 1976), but paradoxically the deepening forces of globalization, transnational mobilities and market-driven development have created increasing numbers, varieties, and scales of enclavic spaces in tourism, limiting people's movement in destination regions. The degree and modes of differentiation or segregation between the hosts and guests/locals and non-locals and their activities can vary greatly, creating different kinds of 
tourism enclaves. Some of the enclaves and their borders are formed relatively loosely, while others are more firmly and visibly established, bordered and sometimes even physically walled. Despite the specific nature and firmness of tourism enclaves and their borders, there are always power issues and processes of inequality involved. As noted by Sidaway (2007, p. 332), “intensified processes and patterns of uneven development are increasingly expressed in enclave spaces." This calls for a better understanding of enclaves and their bordering processes, transformation, and local connections in tourism development. Based on existing literature, the purpose of this paper is to discuss and clarify the conceptual idea of tourism enclaves. Further, the paper aims to connect the research on tourism enclaves with border studies and development geographies, as these academic areas share many common elements but are rarely brought together. In addition, the purpose is to overview some of the key theoretical perspectives on how enclavic spaces are produced, bordered, and governed in contemporary tourism planning and development discourses and practices.

\section{Tourism Enclaves: Products of Territorialization and Bordering}

\section{Bordering Processes}

Past research on enclaves has focused on issues such as control, power, and dependency; bordermaking/bordering; globalization, transnationalism, and (im)mobilities; governance and neoliberalism; otherness, poverty, and uneven development; segregation, participation, and inequality; and authenticity and homogeneous/heterogeneous spaces, for example (see Hampton, 2005; Minca, 2000; Sidaway, 2007; Turner, 2007; Vinokurov, 2007). In addition, enclaves have been approached from an industrial perspective (as enclave economies) in which export-based industrial operations are dominated by non-local actors, capitals, and/or products (see Phelps, 
Atienza, \& Arias, 2015). All of these dimensions are highly applicable perspectives for enclave research in tourism.

Conceptually, enclaves can be understood as products of (human) territorialization and bordermaking. For Sack (1986, p. 1), territoriality is "a spatial strategy which can be employed to affect, influence, or control resources and people, by controlling area." As a process, it is a form of control that involves two dimensions: Organizing space and creating boundaries that serve to facilitate that organization. Boundaries and bordering often refer to a nation state's affairs, but as indicated by Rumford (2012, p. 887), bordering and bounded spaces "are not always the project of the state" as people, entrepreneurs, and NGOs can also actively construct and transform borders or in some cases even erase them (Rumford, 2008; Timothy, Saarinen \& Viken, 2016). Rather than erasing or creating the mutual connectivity of borders, enclavic spaces are usually seen as expressions of exclusive borderwork, where mobilities and encounters are somehow curtailed and differences and inequalities between "insiders and outsiders" are reinforced. This exclusive borderwork immobilizing flows of people, goods, and services at a local or regional scale can be based on social, cultural, political, and economic exclusions, among others (see Turner, 2007; Yoon, 2013). The bordered enclaves are not static, however, as they transform and can be contested by different actors, and this transformative nature of enclaves has been recognized in previous tourism research (see Cohen, 2006; Lloyd, 2006).

\section{Tourism Enclaves}

Enclavization processes are increasingly characteristic of transnational tourism development and planning practices in many parts of the world. In tourism research, enclaves refer to a form of development and planning characterized by socio-spatial regulations of host-guest relations and 
related mobilities, where tourists are encouraged to stay and consume inside the self-contained resort environment (Shaw \& Shaw, 1999). Typically, international all-inclusive resorts and package tours, where the offered products and services are included for one prepaid price, are characterized by the elements of enclave tourism. In these kinds of development cases, the tourist-generating economies organize the package tour products, including transportation, accommodation, and excursions, in a way that they have a capacity to regulate and control tourist expenditures through limiting their mobility, to the relative exclusion of the petty producers and other local service providers (Britton, 1982; Gamez \& Angeles, 2010).

A common note in tourism research is that enclaves are a little understood and studied subject (see Shaw \& Shaw, 1999, p. 69). However, it is field of research with a relatively long tradition in tourism: Knebel (1960), for example, focused on sites characterized by a "touristic own inner world" (touristiche Eigenwelt) and MacCannell's $(1973,1976)$ staged authenticity with front and back stage formations refers to the process of bordering and potentially resulting enclavization in tourism. There are also different neighboring terms used in research, such as "environmental bubble" (Cohen, 1972), "tourist bubble" (Adiyia et al., 2015; Jacobsen, 2003; Judd, 1999) and "tourist utopia" (Simpson, 2016), referring to enclaves.

A specific definition of a tourism enclave depends partly on a selected viewpoint, as they can be approached from production, consumption, living, or governance perspectives. Generally, the tourism enclaves have been conceptualized as "a well-defined perimeter [that] separates the tourism space" from the rest of socio-spatial environment (Judd, 1999, p. 16) or as spaces that are "in some ways isolated and separated from wider society" (Weaver, 2005, p. 168). However, this separation does not mean that the tourism enclaves are created, bordered, consumed, and governed in a vacuum. On the contrary, they are seen as being "operated by global capital and transnational 
organizations through a series of spatial networks, which unless they are strongly regulated by the local state, allow only limited economic benefits to accrue to the host communities" (Shaw \& Shaw, 1999, p. 68).

In this respect, the bordering process in enclave spaces can be highly selective. For example, the planning and development of casino resorts under the apartheid regime in South Africa was based on a separation between whites and "the rest" (see Rogerson, 1990; Wellings \& Crush, 1983). At the same time, however, these racialized tourism enclaves located in Bantustans (i.e., so-called black homelands) selectively allowed otherwise illegal activities in South Africa, such as interracial relations, to take place legally (Rogerson, 2014, p. 25; see Harrison, 1992).

While tourism enclaves can be identified as products of transnational forces in a global-local nexus, it is also important to understand the history and transformative nature of enclaves. Like any place or region, tourism enclaves are historically contingent processes (see Gilbert, 1960; Pred, 1984), where "regional and local patterns of ethnic segregation that pre-date tourism development shape their specific configurations" (Manuel-Navarrete, 2016, p. 508). Thus, while the global tourism industry often plays a major and highly visible role in the formation of enclaves, there can be other contextual elements involved that shape the nature and development paths of these sites.

\section{Development and Transformation of Tourism Enclaves}

A key research topic in enclave tourism has been their development and organization. As an idea, development is complex, often contradictory and, thus, challenging to define. According to Lawson (2007, p. 5) there are "two connected threads of meaning in development": development as a concrete material process and as a discourse. These two aspects come together in tourism enclave 
development characterized by physically and symbolically distinguished spaces from their surrounding environments. In addition, Hart (2001, p. 650) has made a distinction “between 'big D' Development defined as a post-Second World War project of intervention in the 'Third World' that emerged in the context of decolonization and the Cold War, and 'little d' development, or the development of capitalism as a geographically uneven, profoundly contradictory set of historical processes." Again, these two configurations of development can characterize (and occasionally come together in) tourism that is promoted as "Development" by global scale institutions, such as the World Bank, the International Monetary Fund and/or different departments of the United Nations (Saarinen \& Rogerson, 2014; Scheyvens, 2011) but which is often driven locally by mainstream tourism businesses and the capitalistic logic of production (Scheyvens, 2009).

Tourism studies have developed different theorizations focusing on enclavic tourism spaces and their formation. Probably the most well-known and used approach is Britton's (1982) enclave model for Third World tourism, which mainly reflects Hart's (2001) development and expansion of the capitalistic system. Britton's seminal paper and model The political economy of tourism in the Third World was based on dependency theory, which implies that peripheral and economically poor regions, mainly located in the Global South, are underprivileged by the way they have been integrated into the global "world system," ruled by the wealthy regions and actors from the Global North.

Britton's (1982) model has a hierarchical structure. The top level of the model is controlled by international tourism corporations and other organizations located in the "metropolitan (i.e., core) economies," where the headquarters of corporations and associated non-tourism companies and related actors are situated. Destination-based branch offices of metropolitan businesses are located in the mid-level of the model, and at the bottom level are small businesses which are highly 
dependent upon the chain of businesses and actors located at the higher levels of the production chain. Thus, the metropolitan companies dominate major facets of the industry and the links in the flow chain of capital, management, goods, transportation, accommodation, and other services from tourist-generating regions into the peripheral enclave and their local distribution inside the enclave (see Carlisle \& Jones, 2012; Scheyvens \& Momsen, 2008). According to the model, the locallyoperating global tourism industry is based on the involvement of multinational corporations and foreign direct investments (FDI), leading to economic leakages and the marginalization of hosts, resulting in further enclavization in tourism development and planning (Gamez \& Angeles, 2010; Mbaiwa, 2005). Thus, the model mainly focuses on the macro-economics of tourism development. In addition, it is tourism-centric and does not fully recognize other contextual and historical elements beyond tourism in destination regions. In respect to the formation and understanding of the dynamics of enclaves, however, these elements beyond tourism (both locally and globally) have been noted to be influential in recent studies (see Buzinde \& Manuel-Navarrete, 2013; Carlisle \& Jones, 2012; Manuel-Navarrete, 2016).

Edensor's (2000) distinction between enclavic and heterogeneous tourist spaces is used as an alternative theoretical approach to thinking about what makes a destination an enclave. For Edensor (2001, p. 63) "tourism takes place within meaningful spatial contexts," where different modes of tourist performances take place. While there are numerous potential stages for tourist activities, Edensor (2001, p. 63) argues that "tourist performance is socially and spatially regulated to varying extents," and this extent or continuum is basically formed on the basis of a conceptual division between "carefully planned and managed," centrally regulated "single purpose" spaces representing "homogeneous" enclaves and "an unplanned bricolage of structures and designs," referring to multipurpose heterogeneous spaces (Edensor, 2001, p. 63-64). The borders in enclave tourist spaces are less porous, while heterogeneous tourist spaces are characterized by "blurred boundaries." In 
relation to borderwork, a crucial aspect in Edensor's approach is the notion of change, i.e., different stages of tourists' performances can continually be transformed under the expansion and development of capitalistic production (see also Hart, 2001). In addition, Edensor's distinction highlights the significance of socio-spatial contextuality and that the production of enclaves is not only "representational" (discursive) but highly material.

There are also other frameworks which can be used in studies focusing on the development of tourism enclaves. For example, Butler's (1980) tourism area life cycle (TALC) model provides a potential tool for analyzing how local and non-local actors and networks operate in tourism development and planning, and how the costs and benefits of tourism are distributed in a transnational production chain (see also Butler 1992). Alternatively, a transformation of the tourism destinations approach highlights the elements of spatial homogenization and differentiation with related discourses and practices of development and socio-spatial identities (Saarinen, 2004). Based on this approach, destinations tend to transform toward more standardized and homogenous tourist spaces mainly serving the needs of non-locals, i.e., visitors, and, at the same time, they are differentiated from their surrounding socio-cultural and economic environment, turning the local tourism development path toward enclavization.

Different theoretical and conceptual perspectives also indicate the different kinds of impacts of enclavic tourism development. These impacts are widely discussed in the literature and they include issues such as economic leakages, dependency, inequalities, low local employment, low level of local salaries, homogenization of products, inauthentic tourist experiences, unsustainability, and so on (see Anderson, 2011; Hampton, 2010; Liu, Liu \& Liu, 2007; Minca, 2000; Shaw \& Shaw, 1999; Wanton, 1993; Weaver, 2005; Wilson \& Richards, 2008; Jacobsen, 2003; Jaakson, 2004). 
Obviously, the nature and level of the impacts depend on the scale of tourism operations and the firmness of borders and borderwork and, thus, the type of tourism enclave.

\section{Types of Enclave Tourism Spaces}

According to Cohen and Neal (2012), four types of tourism enclaves can be identified in the previous literature: Resort enclaves, backpacker enclaves, urban tourist enclaves, and religious tourist enclaves. In brief, resort enclaves typically refer to seaside tourism destinations dominated by the consumption of wealthy visitors from the Global North "in poor, rural host surroundings in developing countries" (Cohen \& Neal, 2012). They are often large scale and spatially and ideologically separated from their socio-economic surroundings (Minca, 2000). In addition to seaside resorts, however, the development of casinos and other luxury tourism destinations can sometimes evolve into resort enclaves (see Rogerson, 1990; Wellings \& Crush, 1983). In contrast to these kinds of tourism resorts, backpacker enclaves are characterized by a small scale but large number of tourist operations that are targeted at relatively young, low-spending, long-term visitors (Cohen \& Neal, 2012). Backpacker enclaves have been particularly studied in South-East Asia (see Cohen, 2006; Lloyd, 2006; Hampton, 1998, 2013; Hottola, 2005; Howard, 2007; Wilson \& Richards, 2008), and they can be located in various geographical contexts in a rural-urban continuum. This can partly blur the boundaries between them and urban tourist enclaves.

In general, urban and backpacker enclaves have much in common, especially with regard to their differences from resort enclaves, as they are both characterized by a multiplicity of establishments with a "softer" and less exclusive borderwork compared to resorts. However, for locals they can both represent "islands of affluence that are sharply differentiated and segregated from the surrounding urban landscape" (Judd, 1999, p. 53). While urban enclaves include those backpacker 
enclaves (e.g., Khao San Road, Bangkok) located inside urban structures, they can also contain, using Edensor's $(2000,2001)$ terminology, many other kinds of "tourist performances" than those typical of backpacking (see Simpson, 2016). For example, Cohen and Neal (2012) have analyzed a Middle Eastern Muslim enclave and its transformation from sex tourism toward medical tourism in Bangkok.

The final type in Cohen and Neal's (2012, p. 571) categorization is the religious tourist enclave. They are simply "based on the religious needs and preferences of observant tourists, and may emerge in both urban and nonurban settings." These enclaves have many potential connections to pilgrimage tourism and religious tourism in general (see Raj \& Griffin, 2015; Timothy \& Olsen, 2006). In addition, a fifth category called a "mobile enclave" can be identified (Weaver, 2005) and added to Cohen and Neal's (2012) original classification. These mobile enclaves are typically large cruise ships that operate in a similar way to resort enclaves, but are not tied to any specific geographical location (Jaakson, 2004), although they usually operate on certain routes and visiting harbors. These cruise ships contain a large number of tourists from the Global North enjoying an all-inclusive package that effectively limits their spending to on board (see Stewart \& Draper, 2006).

Depending on the type of enclave, the nature of borderwork and border-making varies. Thus, there is a different "tightness and selectiveness of boundaries." Compared to backpacker and urban enclaves, resort (and cruise) enclaves located outside the local communities have firmer borders, keeping visitors and locals separated or limiting and more clearly defining roles in encounters. Locals can enter the enclaves as workers but may not be able to do so for leisure purposes in their free time. Thus, the bordering of enclaves can be selective, and in extreme cases enclavization can lead to a "walling" with physical constructions around enclosures (Scheyvens, 2011; see Jefferey, 
McFarlane \& Vasudevan, 2012). Therefore, the selectiveness of borders often involves inequalities that challenge the sustainability of tourism development in enclave contexts.

\section{Discussion and Conclusions}

Past research on tourism enclaves has focused on describing and classifying enclaves with empirical case studies from consumer and local population perspectives. In addition, the nature and impacts of enclavic tourism economies and operations have been analyzed. From the local community perspective, research has been largely designed to demonstrate the inequalities and exclusions in development and benefit sharing in Global South contexts, with critical approaches based on dependency theory. Recently, less tourism-centric approaches have been highlighted by emphasizing a need to recognize the heterogeneous nature of enclaves and their historic pre-tourism development processes (Manuel-Navarrete, 2016). Indeed, the nature and identity of a tourism enclave contains features not only from the present but also traces, practices, and ideologies from the past transformations of the place (Saarinen, 2004). This transformative nature and the evolution of enclaves, including a potential dissolution of past enclaves due to changing political and economic structures, are relatively little studied perspectives in tourism geographies (see Rogerson, 2014).

Enclave tourism is a growing field of research, and enclaves or enclavic processes are rather common features in current tourism development and management situations dominated by external forces, actors, and power inequalities (see Sidaway, 2007). This is especially the case in lowincome countries or similar regions, where, e.g., former communal lands for livestock use and agriculture or common beach areas have been "privatized" by international tourism operators and neoliberal interventions. Thus, deepening globalization and the fluidity of contemporary societies 
have not obviously resulted in equal "rights of mobility" in transnational tourism development contexts. In this respect, enclaves represent and communicate power relations: They facilitate control and mobilities over space. Enclave spaces represent a form of tourism development that is often controlled, managed and/or dominated by transnational operators and at the same time, the locals' access to these spaces is regulated. In extreme cases, enclavic tourism planning and development processes segregate locals from the tourism spaces and related development opportunities, representing a form of "neo-colonization" (see Bianchi, 2009; Hall \& Tucker, 2004; Minca, 2000). However, enclavization is not necessarily driven by transnational or other external forces, as local historical and ethnic relations can also reinforce enclavic distinctions in (tourism) development and participation. Therefore, tourism cannot always be arraigned as the sole or even as a main driver in the enclavization process.

Based on existing literature, enclave tourism seems to be a highly suspicious mode of tourism development and planning. It is seen as a very concentrated form of tourism with homogenized and standardized products dominated by global capital and actors and foreign tourists' (and/or national elites) consumption needs. As a process, enclave tourism tends to lead to high economic leakages and limited benefits for local communities, low levels of employment and salaries, seasonal work, and so on. Basically, enclave tourism is seen as an unsustainable form of tourism and an antithesis to inclusive growth and development thinking, which characterizes the current political and economic discussions in the Global South (Saarinen \& Rogerson, 2014).

Despite the suspicious and unsustainable nature of enclaves, there is also "reasoning" for their existence, as they are rather common features in many tourism development contexts. First, from the perspectives of the industry's neoliberal growth and market-driven governance, they are probably an economically efficient way to organize and manage tourism, especially in foreign 
operational environments in the Global South and other peripheries. In this respect, tourism enclaves can resemble well-defined industrial zones controlled and governed by external actors. Secondly, from the tourists' perspective, they are "easy products" to consume. As noted by Butler (1990, p. 40), "many people seem to enjoy being a mass tourist," and enclaves with all-inclusive products with a single price paid in the tourists' home regions covering all expenses most probably satisfy customers looking for relaxation and highly organized tourism spaces and products. Obviously, enclave tourism development is not only characterized by mass tourism but also by backpackers or high-end (high-value) tourist segments, for example. In the latter case, a distinction and exclusiveness from "mainstream tourists" is based on pricing, and this search for luxury can lead to serenity from the "tourist crowds" and eventually also result in spatial exclusion from local people and their businesses.

In the worst case, these enclavic "gated communities of tourism" with their all-inclusive products can turn out to be all-exclusive spaces for local communities in development. Thus, selective inclusiveness and exclusiveness characterize tourism enclaves and their transformation. From a sustainable tourism perspective, these kinds of planning and development modes and practices can be seen as highly undesirable. In order to understand the nature and development of enclave tourism and how to guide their transformation in more sustainable directions, critical research on policy and governance aspects of enclave tourism is needed. In this respect, the key perspectives to analyze are related to the processes and practices of territorialization and bordering, as they ultimately define the scale and nature of enclavic development, host-guest encounters, and the selective openness or closeness of enclaves and their borders for the locals and visitors. By focusing on the borderwork in enclave tourism, it may be possible to analyze the potential connectivity of borders and how they could also empower cultural, social, economic, and political encounters and learning (Rumford, 2012), instead of selective exclusive development and immobilization on the local scale. This kind 
of research agenda calls for further social theoretization, but also requires conceptually wellinformed case studies conducted in diverse empirical settings in the Global South and Global North.

\section{References}

Adiyia, B., Stoffelen, A., Jennes, B., Vanneste, D., Ahebwa, W. (2015). Analysing governance in tourism value chains to reshape the tourist bubble in developing countries: the case of cultural tourism in Uganda. Journal of Ecotourism, 14, 113-129. doi:10.1080/14724049.2015.1027211 Anderson, W. (2011). Enclave tourism and its socio-economic impact in emerging destinations. Anatolia, 22, 361-377. doi: 10.1080/13032917.2011.633041

Bianchi, R. (2009). The 'Critical Turn' in Tourism Studies: A Radical Critique. Tourism Geographies, 11, 484-504. doi:10.1080/14616680903262653

Britton, S. (1982). The Political Economy of Tourism in the Third World. Annals of Tourism Research, 9, 331-338. doi:10.1016/0160-7383(82)90018-4

Britton, S.G. (1991). Tourism, capital, and place: towards a critical geography of tourism. Environment and Planning D: Society and Space, 9, 451-478. doi:10.1068/d090451

Brohman, J. (1996). New directions in tourism for third world development. Annals of Tourism Research, 23, 48-70. doi:10.1016/0160-7383(95)00043-7

Butler, R. (1980). The concepts of a tourist area cycle of evolution: implications for management of resources. Canadian Geographer, 24, 5-12. doi: 10.1111/j.1541-0064.1980.tb00970.x Butler, R. (1990). Alternative tourism: Pious hope or Trojan Horse? Journal of Travel Research, 28, 40-45. doi:10.1177/004728759002800310

Butler, R. (1992) Alternative tourism: the thin edge of the wedge. In Smith, V.\& W.R. Edington (Eds.), Tourism Alternatives (pp. 31-46). Philadelphia, PA: Philadelphia University Press. 
Buzinde, C.N. \& Manuel-Navarrete, D. (2013). The social production of space in tourism enclaves: Mayan children's perceptions of tourism boundaries. Annals of Tourism Research, 43, 482-505. doi:10.1016/j.annals.2013.06.003

Carlisle, S. \& Jones, E. (2012). The Beach Enclave: A Landscape of Power. Tourism Management Perspectives, 1, 9-16. doi:doi:10.1016/j.tmp.2011.12.003

Castells, M. (1996). The information age: economy, society and culture. Volume I: the rise of the network society. Oxford: Blackwell.

Cohen, E. (1972). Towards a sociology of international tourism. Social Research, 39, 164-182.

Cohen, E. (2006). Pai - A backpacker enclave in transition. Tourism Recreation Research, 31, 1127. doi:10.1080/02508281.2006.11081502

Cohen, E. \& Neal, M. (2012). A Middle Eastern Muslim Tourist Enclave in Bangkok. Tourism Geographies, 14, 570-598. doi:10.1080/14616688.2012.647320

Dürr, E. (2012) Encounters over garbage: tourists and lifestyle migrants in Mexico. Tourism Geographies, 12, 339-355. doi: 10.1080/14616688.2012.633217

Edensor, T. (2000). Staging tourism: tourists as performers. Annals of Tourism Research, 27, 322344. doi:10.1016/S0160-7383(99)00082-1

Edensor, T. (2001). Performing tourism, staging tourism: (Re)producing tourist space and practice. Tourist Studies, 1, 59-81. doi:10.1177/146879760100100104

Freitag, T.G. (1994). Enclave tourism development: For whom the benefits roll? Annals of Tourism Research, 21, 538-554. doi:10.1016/0160-7383(94)90119-8

Gamez, A. \& Angeles, M. (2010). Borders within. Tourism growth, migration and regional polarization in Baja California Sur (Mexico). Journal of Borderland Studies, 25, 1-18.

Gibson, C. (2010). Geographies of tourism: (un)ethical encounters. Progress in Human Geography, 34, 521-527. doi:10.1177/0309132509348688 
Gilbert, E.W. (1939). The growth of island and seaside health resorts in England. Scottish Geographical Magazine, 55, 16-35.

Gilbert, E.W. (1960). The Idea of the Region. Geography, 45, 157-175.

Hall, C.M., \& Tucker, H. (Eds.)(2004). Tourism and postcolonialism: Contested discourses, identities and representations. London: Routledge.

Hampton, M. (1998). Backpacker tourism and economic development. Annals of Tourism Research, 25, 639-660. doi:http://dx.doi.org/10.1016/S0160-7383(98)00021-8

Hampton, M. (2005). Heritage, local communities and economic development. Annals of Tourism Research, 32, 735-759. doi:http://dx.doi.org/10.1016/j.annals.2004.10.010

Hampton, M. (2010). Enclaves and ethnic ties: The local impacts of Singaporean cross-border tourism in Malaysia and Indonesia. Singapore Journal of Tropical Geography, 31, 239-253. doi:10.1111/j.1467-9493.2010.00393.x Hampton, M. (2013). Backpacker Tourism and Economic Development: Perspectives from the Less Developed World. London: Routledge.

Hannam, K., Sheller, M., Urry, J. (2006). Mobilities, immobilities and moorings. Mobilities, 1, 122. doi:10.1080/17450100500489189

Harrison, D. (1992). Tradition, modernity and tourism in Swaziland. In Harrison, D. (Ed.), Tourism and the less developed countries (pp. 148-162). London: Belhaven Press.

Hart, G. (2001). Development critiques in the 1990s: culs de sac and promising paths. Progress in Human Geography, 25, 649-658. Doi:10.1191/030913201682689002

Hart. G. (2004). Geography and development: critical ethnographies. Progress in Human Geography, 28, 91-100. doi:10.1191/0309132504ph472pr

Hottola, P. (2005). The metaspatialities of control management in tourism: Backpacking in India. Tourism Geographies, 7, 1-22. doi:10.1080/1461668042000324030 
van Houtum, H., Kramsch, O. \& Zierhofer, W. (2005). Prologue: B/ordering Space. In van Houtum, H. Kramsch, O. \& W. Zierhofer (Eds.), B/ordering Space (pp. 1-13). Aldershot: Ashgate.

Howard, R. (2007). Five backpacker enclaves. International Journal of Tourism Research, 9, 7386. doi:10.1002/jtr.593

Jaakson, R. (2004). Beyond the tourist bubble? Cruiseship passengers in port. Annals of Tourism Research, 31, 44-60. doi: 10.1016/j.annals.2003.08.003

Jacobsen, J.K.S. (2003). The tourist bubble and the Europeanisation of holiday travel. Tourism and Cultural Change, 1, 71-87.

Jeffrey, A., McFarlane, C. \& Vasudevan, A. (2012). Rethinking enclosure: space, subjectivity and the commons. Antipode, 44, 1247-1267. doi:10.1111/j.1467-8330.2011.00954.x

Judd, D. (1999). Contracting the tourist bubble. In D. Judd \& S. Fainstein (Eds.), The tourist city (pp. 35-53). New Haven: Yale University Press.

Knebel, H-J. (1960). Soziologische strukturwandlungen im modernen tourismus. Stuttgart: Enke Knoblich.

Liu, A., Liu, J. \& Liu, M. (2007). Progress in enclave tourism study of overseas: A literature review. Chinese Journal of Population, Resources and Environment, 5, 76-81.

Lloyd, K. (2006). Catering to the backpacker: The transition of backpacker enclaves in Vietnam. Tourism Recreation Research, 31, 65-73. doi:

MacCannell, C. (1973). 1973 Staged Authenticity: Arrangements of Social Space in Tourist Settings. American Journal of Sociology, 79, 589-603.

MacCannell, D. (1976). The tourist: A new theory of the leisure class. New York: Schoken Books. Manuel-Navarrete, D. (2016). Boundary-work and sustainability in tourism enclaves. Journal of Sustainable Tourism, 24, 507-526. doi:10.1080/09669582.2015.1081599

Mbaiwa, J. (2005). Enclave Tourism and its Socio-economic Impacts in the Okavango Delta, Botswana. Tourism Management, 26,157-172. doi:10.1016/j.tourman.2003.11.005 
Minca, C. (2000). 'The Bali Syndrome': The explosion and implosion of 'exotic' tourist spaces.

Tourism Geographies, 2, 389-403. doi: 10.1080/146166800750035503

Ohmae, K. (1990). The Borderless World. New York: Harper Business.

Paasi, A. (2009). Bounded spaces in a 'borderless world': border studies, power and the anatomy of territory. Journal of Power, 2, 213-234. doi:10.1080/17540290903064275

Phelps, N., Atienza, M. \& Arias, M. (2015). Encore for the Enclave: The Changing Nature of the Industry Enclave with Illustrations from the Mining Industry in Chile. Economic Geography, 91, 119-146. doi: 10.1111/ecge.12086

Pred, A. (1984). Place as a historically contingent process: structuration and the time-geography of becoming places. Annals of Association of American Geographers, 74, 279-297.

Raj, R. \& Griffin, K. (Eds.)(2015). Religious Tourism and Pilgrimage Management: An International Perspective. Oxfordshire: CABI.

Rogerson, C.M. (1990). Sun international: The making of a South African tourismus multinational. GeoJournal, 22, 345-354. doi:10.1007/BF00192834

Rogerson, C.M. (2014). Rethinking slum tourism: tourism in South Africa's rural slumlands. Bulletin of Geography. Socio-economic Series, 26, 19-34. Doi: http://dx.doi.org/10.2478/bog-20140042

Rumford, C. (2008). Citizens and borderwork in contemporary Europe. London: Routledge.

Rumford, C. (2012). Towards a multiperspectival study of borders. Geopolitics, 17, 887-902. doi:10.1080/14650045.2012.660584

Saarinen, J. (2004). 'Destinations in Change': the Transformation Process of Tourist Destinations. Tourist Studies, 4, 161-179. doi: 10.1177/1468797604054381

Saarinen, J. \& Rogerson, C.M. (2014) Tourism and the Millennium Development Goals: Perspectives Beyond 2015. Tourism Geographies, 16, 23-30. doi:10.1080/14616688.2013.851269 
Scheyvens, R. (2009). Pro-Poor Tourism: Is there value beyond the rhetoric? Tourism Recreation Research, 34, 191-196.

Scheyvens, R. (2011). Tourism and Poverty. London: Routledge.

Scheyvens, R. \& Momsen, J. (2008). Tourism and poverty reduction: Issues for small island states. Tourism Geographies, 10, 22-41. doi:10.1080/14616680701825115

Shaw, B. \& Shaw, G. (1999). 'Sun, sand and sales': Enclave tourism and local entrepreneurship in Indonesia. Current Issues in Tourism, 2, 68-81. doi:10.1080/13683509908667844

Sidaway, J. (2007). Enclave Space: A New Metageography of Development? Area, 39, 331-339.

Simpson, T. (2016). Tourist utopias: biopolitics and the genealogy of the post-world tourist city. Current Issues in Tourism, 19, 27-59. doi:10.1080/13683500.2015.1005579

Stewart, E. \& Draper, D. (2006). Sustainable Cruise Tourism in Arctic Canada: An Integrated Coastal Management Approach. Tourism in Marine Environments, 3, 77-88. doi: http://dx.doi.org/10.3727/154427306779435210

Timothy, D. \& Olsen, H. (Eds.)(2006). Tourism, Religion and Spiritual Journeys. London: Routledge.

Timothy, D. Saarinen, J. \& Viken, A. (2016). Tourism Issues and International Borders in the Nordic Region. Scandinavian Journal of Hospitality and Tourism, 16, (in press)

Torres, R. \& Momsen, J. (2005). Gringolandia: The construction of a new tourist space in Mexico. Annals of the Association of American Geographers, 95, 314-335. doi:10.1111/j.14678306.2005.00462.x

Turner, B.S. (2007). The enclave society: towards a sociology of immobility. European Journal of Social Theory, 10, 287-303. doi:10.1177/1368431007077807

Vinokurov, E. (2007). A theory of enclaves. Lanham: Rowman \& Littlefield Publishers.

Walton, J. (1993). Tourism and Economic Development in ASEAN. In Hitchcock, M. King, V. \& M. Parnwell (Eds.), Tourism in South-East Asia (pp. 244-233). London: Routledge. 
Weaver, A. (2005). Spaces of containment and revenue capture: 'Super-sized' cruise ships as mobile tourism enclaves. Tourism Geographies, 7, 165-184. doi:10.1080/14616680500072398 Wellings, P. \& Crush, J. (1983). Tourism and dependency in Southern Africa: the prospects and planning of tourism in Lesotho. Applied Geography, 3, 205-223. doi:10.1016/0143$6228(83) 90027-9$

Wilson, J. \& Richards, G. (2008). Suspending reality: An exploration of enclaves and the backpacker experience. Current Issues in Tourism, 11, 187-202. doi:10.2167/cit371.0 Yoon, S.J. (2013) Mobilizing ethnic resources in the transnational enclave. International Journal of Sociology, 43, 29-54. doi:0.2753/IJS0020-7659430302 